\title{
The service retinues of the Chola court: a study of the term velam in Tamil inscriptions
}

\author{
Daud Ali \\ School of Oriental and African Studies \\ da7@soas.ac.uk
}

\begin{abstract}
Drawing on the large corpus of Chola period Tamil inscriptions, this paper attempts to clarify the meaning of the apparently obscure and neglected term in Tamil epigraphy, known as velam. The paper argues that the term in Chola period sources should best be understood as a "palace establishment" composed mostly of women (and sometimes men) of servile status. A relatively comprehensive review of the term in inscriptions and literature sheds significant light on the organization of the lower echelons of labour in the Chola royal household and the conditions under which men and women of this status were incorporated into such service. The paper argues for a reconsideration of the importance of the velam as an institution in Chola times, as well as the lives of its members, concluding with reflections on how the institution changed over time.
\end{abstract}

\section{Introduction}

As important as aristocratic and royal lineages have been in the shaping of society and culture in early medieval India, very little is understood about the organization of labour in the palaces and extended households of royal families. ${ }^{1}$ While we have a rudimentary understanding of the officers and functionaries who surrounded the king, the organization of the lower echelons of royal service have been far from clear. Yet the worlds of these men and women are manifestly important for a number of reasons. Understanding the social origins of palace servants, the avenues through which they entered service, the privileges and/or constraints falling upon them as a result of their condition, the means of their remuneration and opportunities for advancement, their kin relations, organization and domestic arrangements - besides having intrinsic interest - throws light on the dynamics of elite societies in early medieval India. The lack of

1 I would like to thank Y. Subbarayalu, Sascha Ebeling and especially Leslie Orr and P. Sundaram for assistance on the interpretation of various inscriptions. Leslie Orr was particularly generous in sharing various aspects of her extensive knowledge of women in Tamil inscriptions and carefully commenting on a final draft of this paper. Special thanks also to S. Swaminathan and the Chief Epigraphist at Mysore for their help in obtaining and in some cases interpreting transcripts and estampages during my research trip there, and James Heitzman for generous assistance in producing the site map. 
scholarly treatment of this world of service is, no doubt, attributable to a scarcity of evidence in many regions and periods. At the same time, there has been an apparent disinclination to push the sources to their limit, to reveal what Noboru Karashima has called the "whisperings" of social history from inscriptions. ${ }^{2}$ In the case of the Chola empire of south India (c. 950-1250), the opportunities for such interpretation may be possible due to the copious epigraphic legacy generally lacking in contemporary north India. ${ }^{3}$

This paper explores the lives of lower ranking servants in the Chola imperial household and the organizations to which they belonged, both of which are poorly understood and rarely treated in the historiography of the period. The evidence for such a task remains problematic, as lithic inscriptions mostly record only those economic transactions which pertained to temple affairs - presenting a fragmentary picture of other aspects of Chola society. Nevertheless, a range of differently ranked personnel associated with the palace appear regularly in inscriptions as donors - their titles and affiliations providing insight into the service arrangements of the royal household. Inscriptional evidence will be supplemented by contemporary literary sources - court poetry, sumptuary manuals, and travellers' accounts. Though precise corroboration is elusive, literary sources remain an important backdrop for the inscriptional data. The Chinese traveller Chau Ju-Kua, for example, who claims to have visited south India sometime in the late twelfth or early thirteenth century, reports that the Chola king retained some 10,000 "dancing girls", three thousand of whom attended him in rotation. ${ }^{4}$ Sumptuary manuals in Sanskrit often rank the majesty of kings by the size of their retinues. The imperial king, according to the architectural treatise Mānasāra, was to have an entourage of millions of women. ${ }^{5}$ In court poetry such women appear as nameless nāyikās, thronging the streets of the royal city seeking the attention of the king as he moves in procession. While these genres contain formulaic dimensions, together they underscore what must have been an extensive presence in the royal household.

From their inscriptions, the Cholas are known to have had a number of palace complexes - at Tanjavur, Gangaikondacholapuram, Kanchi and Palaiyaru, to name those cited most frequently. ${ }^{6}$ Though no medieval palace has survived intact, incidental inscriptional references suggest that

2 Noboru Karashima, "Whispering of inscriptions", in Kenneth R. Hall (ed.), Structure and Society in Early South India: Essays in Honour of Noboru Karashima (Delhi: Oxford University Press, 2002), 56-7.

3 Chola period inscriptions are published chiefly in South Indian Inscriptions (henceforth SII), Epigraphia Indica (henceforth EI) and the Travancore Archaeological Series (henceforth $T A S$ ). Unpublished inscriptions have been noted in the Annual Reports on Indian Epigraphy (henceforth ARE).

4 Reported originally in the account called Ling-wai-tai-ta. See Chau Ju-Kua: His Work on the Chinese and Arab Trade in the Twelfth and Thirteenth Centuries Entitled Chu-fan-chi, trans. F. Hirth and W.W. Rockhill (Taipei: Cheng Wen Publishing Co., 1970), 95, 100.

5 See Mānasāra, ed. P.K. Acharya (Delhi: Oriental Reprints, 1980), vol. 3, 41.10-43.

6 Tamil and Sanskrit diacritics will not be used for modern place names or major dynasties current in English-language scholarship. Epigraphic spelling conventions 
palace-complexes were composed of numerous, and often large, multistoreyed residences as well as functionally defined buildings, like bathing-, eating-, and assembly halls. In some cases, palaces were also connected to surrounding urban space. Inscriptions mention "inner" and "outer" regions of the city, and literary texts indicate that the streets surrounding palace complexes often housed a sort of extended retinue of the king. These spatial arrangements seem to be broadly corroborated by contemporary sources on architecture and town planning.

The inhabitants of royal palaces of course included first and foremost the royal family itself, which was of a considerable size. In order to secure political alliances, Chola kings frequently took numerous wives. Two kings in the tenth century, for example, Parāntaka I (907-955) and Uttamacōla (979-985), are known to have had at least ten wives each. ${ }^{7}$ Many of these women appear in the epigraphic records as donors - acting individually or collectively, but often independently of their husbands. The royal household would have also included children as well as various other kin of different ages - though beyond the heir-apparent and the viceroys of the eleventh century, these people do not regularly appear in the epigraphic record.

Beyond family, the royal household may have retained various high state functionaries, and certainly included personal body guards and some hereditary military retainers. Then there were special "intimates" (anukkan/ anukki), "concubines" (pokiyār), and "friends" (saciva) who enjoyed elevated status and sometimes lordly titles. These people often appear as members of the heterogeneously staffed retinues or entourages (parivārams) which accompanied high ranking family members as they moved between royal centres and toured the kingdom making religious donations. Finally, there was a much wider group of personal or "domestic" servants who occupied a lower rank in the royal household, but who are nevertheless relatively conspicuous in the inscriptional record. These men and women are referred to in inscriptions by generic terms like pentattti ("servile woman") and panimakan ("work-boy"). ${ }^{8}$ It is these latter groups who form the subject of this paper.

\section{The velam as an institution}

A key term which appears regularly in inscriptions associated with palace servants, particularly women, is the Tamil word "velam". Over thirty different velams are mentioned in twice as many inscriptions, all dated

(particularly the use of short vowels) will be maintained for Tamil cited from inscriptions despite their discrepancy with standard literary usage.

7 Notable are the marriages secured with the Malaiyamāns of Milādu, the Malavars of Malāụu, Irukkuveḷ of Kodambalūr as well as the Vallavaraiyar and Paluvețtaraiyar lineages. See George Spencer, "Ties that bind: royal marriage alliance in the Chola period", Proceedings of the Fourth International Symposium on Asian Studies (Hong Kong: Asian Research Service, 1982), 717-36.

8 On panimakan, see Subbarayalu, Studies in Chola History (Chennai: Surabhi Pathipakam, 2001), 107. 
between the reigns of Parāntaka I (907-955) and Kulōttunka I (10701120). ${ }^{9}$ The inscriptions are primarily concentrated in the Chola core region with smaller numbers located in outlying regions (see Figure 1). Translated variously as "harem", "prison", palace, or "military encampment", the term has received little by way of systematic attention, and its origin and precise meaning remain uncertain. ${ }^{10}$ Its obscurity is partly attributable to a limited appearance in the sources. The term is confined entirely to the Chola period, and even then its incidence is substantial, but hardly copious - it occurs in just under sixty inscriptions (many of which are unpublished) and in a single literary text. ${ }^{11}$ Moreover, its meaning is often ambiguous, leaving it open to a wide array of interpretations by historians and epigraphists.

In the great majority of inscriptional references, velams are mentioned as the identifiers of particular male and (mostly) female donors at temples. Typically, incidences have a similar syntactic structure: $x$ velattup pentâtțti $y$, where $x$ refers to the title of the velam and $y$ the name of the woman. The titles of velams give us significant clues as to their function and organization. The designation of many velams clearly derive from the names of kings and queens and other members of the royal family and the many titles which they bore. Chola kings, as is well known, had a predilection for naming institutions, territorial units and even denominations of measure after themselves and their relations. Palace institutions were no different. So in the tenth century, during the reign of Parāntaka and his immediate successors, we learn of velams named after the Chola queens Karralipirātțiyār and Kilānațikal as well as the prince Gaṇuarāditya. ${ }^{12}$ During the reign of Rājarāja I (985-1014), inscriptions at Tanjavur and elsewhere record the names of no fewer than nine velams with royal titles (most of which were associated with Rājarāja himself), and at least one velam named after his queen Pañcavanmādeviyār. This practice of titularly naming continued well into the twelfth century.

9 My research revealed approximately 100 inscriptions directly relevant for this study, nearly sixty of which explicitly mention velams. Fewer than half of this overall number have been published. I was able to consult transcripts or estampages of a large number of these unpublished inscriptions at the Chief Epigraphist's Office (Archaeological Survey of India) in Mysore, but a few of these records have remained elusive and untraceable.

10 See T. N. Subramaniam, "Glossary", in South Indian Temple Inscriptions (Madras: Government Oriental Manuscript Library, 1957), vol. 3, pt. 2, s.v.; Nilakanta Sastri, The Colas (Madras: University of Madras, 1955), 449-51; B. Venkataraman, Rajarajesvaram: The Pinnacle of Chola Art (Madras: Mudgala Trust, 1985), 251; James Heitzman, Gifts of Power (Delhi: Oxford University Press, 1997), 149; and Y. Subbarayalu (ed.), Tamil Kalvețtuc Collakarāti (Chennai: Cānti Cātana, 2002), s.v.; Ci. Kōvintarācan, Kalvettuk Kalaiccol Akaramutali (Madurai: Madurai Kamaraj University, 1987), s. v.; L. Thyagarajan, "Gangai and its region: an epigraphical perspective", in Pierre Pichard et al., Vingt ans après Tanjavur, Gangaikondacholapuram (Paris: École Française d'Extrême Orient, 1994), vol. 1, 184.

11 It is not found in later lexicons like the Apitāna Cintāmaṇi of Mutaliyār Ciñkaravēlu. The Madras Tamil Lexicon (Madras: Madras University, 1927-35), s.v., cites its single literary occurrence in the Chola period poem Kalinkattupparani.

12 For Karralipirātțiyār, see SII 19.131, for Kilānațikal see SII 19.150; SII 17.530; and SII 3.201; for prince Gaṇḍarāditya, see $A R E-\overline{2} 41$ of 1926. 


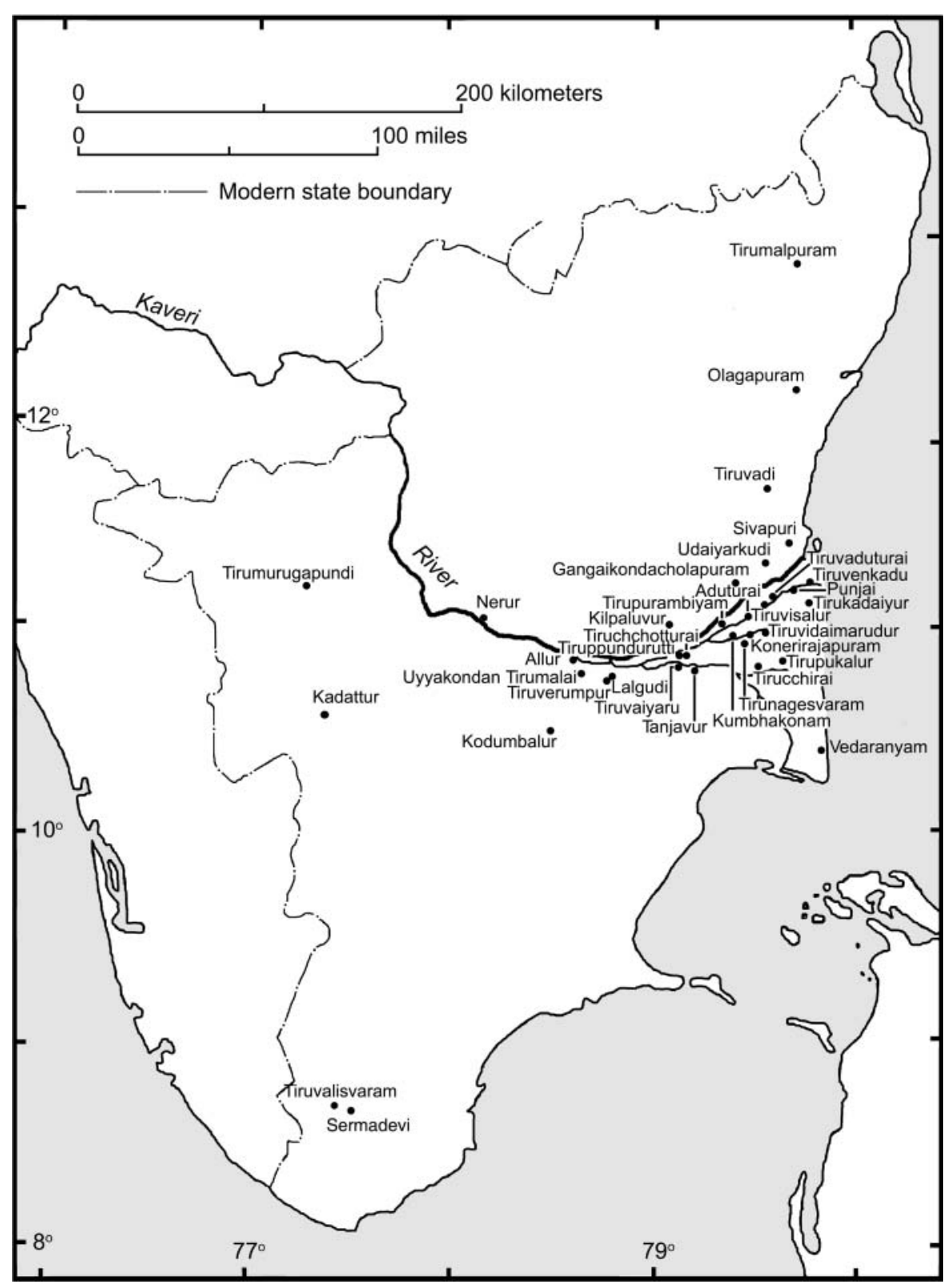

Figure 1. Spatial distribution of velam inscriptions

In some cases, the title of a velam may have indicated attachment to the family member denoted in its title. But this is far from certain. For one, we find velams named after the titles of kings known to be deceased. ${ }^{13}$ So in the reign of Rājarāja we find a number of references to one Kotanțarāma-veḷam, a

13 The evidence here is uncertain due to the large number of names that kings often took and the fact that they often appropriated the titles of their ancestors. 
well-known title of the famous Chola prince Rajāaditya, slain at the battle of Takkolam in $949 .{ }^{14}$ Similarly, during the reign of Rājendra I (1012-1044) and his son Rājendra II (1052-1064), we find references to velams apparently named after the titles of the deceased Rājarāja I (Śivapādaśekhara, Abhimānabhūṣaṇa, Uyyakonțānn). ${ }^{15}$ Moreover, some inscriptions clearly suggest that the names of velams had little to do with the service-affiliations of their members. In one inscription a member of the Kotantarāma-velam is named as a servant of queen Pañcavanmādeviyār. ${ }^{16}$ The Satrubhayanakara-velam, apparently named after a title of Rājarāja or some earlier king, appears to have served the same queen. ${ }^{17}$ The royal names in the titles of these velams, then, do not seem to indicate clearly to whom their services were directed. It is possible that velams, much like brahmadeyas, were named after their founders rather than the individuals they served. Their names may have also been commemorative of past lineage members. Finally, velams titled after deceased kings could also represent the survival of palace institutions founded in earlier times. It is also clear that multiple velams named after different members of the royal family could co-exist at the same time regardless of their service arrangements.

Some have interpreted velam as a military retinue or encampment. ${ }^{18}$ While there is some evidence, as we shall see, that soldiers, particularly those known as kaikkōlars, were sometimes associated with velams, nothing suggests that velams themselves were military encampments or institutions attached to them. It is significant that military units known from other inscriptions whose titles are identical to velam titles (Gaṇarāäditya-velam, Kotaṇțarāma-veḷam and Madhurāntaka-veḷam) are all in fact associated with units of kaikkōlar troops (Gaṇḍarāditta-terinta-kaikkōḷar, Kotanțarāmaterinta-kaikkōlar, and Madhurāntakat-terinta-kaikkōlar). ${ }^{19}$ The velams which can be linked in title with such military units are, however, very limited, and in one case where we have a kaikkọlar explicitly named as a member of a military unit called the Madhurāntaka-terinta-kaikkōla-pațai, his velam affiliation is with the Perumānațikal-Cōlamāteviyār-velam in Tanjavur, presumably a velam named after the queen. It would seem, then, that while military units and velams could overlap, they were formally distinct. In the majority of cases, however, there is no connection at all with a military unit.

14 SII 23.278; SII 23.356; and most probably SII 23.342. The inscriptions during Rājarāja's time at Rājarājeśvara in Tanjavūr also mention one Uttamacīliyārvelam, perhaps a reference to his uncle Uttamacōla, SII 2.94, 95.

15 ARE 63 of 1928; ARE 64 of 1928; ARE 212 of 1911; ARE 121 of 1914. Deciding the actual designees of royal titles can sometimes be tricky, due to the plethora of names taken by each king and the tendency of preserving and appropriating the titles of forebears.

16 SII 23.278 .

17 ARE 62 of 1928.

18 See Kōvintarācan, Kalvețtuk Kalaiccol Akaramutali, s.v. "vēlattup pențātț̣i" and Thyagarajan "Gängai and its region: an epigraphical perspective", 184.

19 See J. Sundaram, "Appendix 1: Military units mentioned in Chola records", in S. N. Prasad (ed.), Historical Perspectives on Warfare in India: Some Morale and Materiel Determinants (Delhi: Centre for Studies in Civilizations, 2002), $243 \mathrm{ff}$. 
Other velam titles suggest more diverse functions. Inscriptions of widely differing dates mention "old" (Palaiya-velam) and "big" (Periya-velam) velams, and a single record mentions an Ālvār-velam, a generic term referring to junior member(s) of the royal household. ${ }^{20}$ There are a handful of inscriptions associated with Chola subordinates in Kongu which refer generically to "the king's" or "royal" velam (Perumāl velam). ${ }^{21}$ Together, these types of titles imply distinctions based on size, pre-eminence and seniority which existed alongside the organization of velams along titular lines. Various other titles suggest functions in the daily routine of the king. A substantial number of records across the tenth and eleventh centuries mention members of the (tiru)mañcanattār-velam or the "velam of the (sacred) bath", ${ }^{22}$ Many of these inscriptions combine the function of bathing with a royal title - we hear of the Uyyakoṇtān-terinta-tirumañcanattārvelam, Rājarāja-terinta-Pāṇti-tirumañcanattār-vẹ̄am, Ilānkeśvarakulakāālaterinta-tirumañcanattār-velam, Rājend̄acoladeva-Mummuticola-terintatirumañcanattār-velam, Ślivapādaśekhara-terinta-tirumañcanattār-velam, and Telingakulakāla-terinta-tirumañcanattār-veḷam. ${ }^{23}$ These long titles, variations on a syntax found in the names of some military units, may be rendered as "the velam known as $x$ (royal title) of those selected for the ceremonial bath". ${ }^{24}$ We find similar velams relating to the handling of ceremonial vessels (Arumolideva-terinta-tiruparikalattār-velam) and "evening rituals" (Abhimānabhūṣaṇa-terinta-tiruvantikkāppu-velam). ${ }^{25}$ While these titles give us our only epigraphic glimpse into the functional activities of velams within the royal household, their evidence should be considered partial. This is because some records mention velam members performing tasks not indicated by their velam affiliations, as when a tenth-century donor, one Nakkan Pattālaki, is identified as a singer in the Periya-velam. ${ }^{26}$

20 For mention of the Palaiya-velam in the tenth century, see SII 3.204 and twelfth century, see SII 5.697. There are ten references to the Periya-velam, making it the most prevalent velam in the sources - a fact which may indicate a relatively low and generic status. In three cases it is specified as the Periya-velam of Rājendra Chola. For tenth-century references, see ARE 99 of 1931, SII 17.480, SII 19.10, and ARE 106 of 1925; for eleventh-century records, see $A R E 104$ of 1925, SII 22.291, $A R E$ 401 of 1921, ARE 424 of 1962, ARE 103 of 1925 and ARE 185 of 1925. For the Ālvārvelam, see SII 23.45. On the significance of the term älvār, see Nilakanta Sastri, The Colas, 142.

21 ARE 334 of 1928; ARE 126 of 1915; ARE 809 of 1983; ARE 825 of 1983.

22 SII 13.15; SII 19.193; SII 22.27; SII 8.678; ARE 510 of 1926; ARE 579 of 1971; ARE 323 of 1965; ARE 325 of 1965; and ARE 149 of 1932.

23 SII 2.94 and 95; ARE 323 of 1927; ARE 142 of 1919; ARE 121 of 1914; ARE 63 of 1928; and ARE 64 of 1928; ARE 149 of 1932.

24 I follow the rendering of Subbarayalu, in Studies in Cola History, 108. A possible alternative reading of this syntax would be "the velam of those selected for the ceremonial bath of $x$ (holder of royal title)". This reading seems unlikely, however, as the royal titles of velams do not seem to imply any necessary affiliative connection.

25 SII 2.94; ARE 212 of 1911. The latter phrase is unclear, but may refer to the application of protective unguents or substances, known as kāppu, in temple ritual, see Leslie Orr, Donors, Devotees, and Daughters of God: Temple Women in Medieval Tamilnadu (New York: Oxford University Press, 2000), 114.

26 SII 19.10 . 
Two inscriptions on the Rājarājeśvara temple at Tanjavur mention "Pāṇtị", short for Pāṇtimaṇțalam, the Chola administrative designation of the conquered Pandya kingdom. We hear of the Pāṇti-velam and the Rājarāja-terinta-Pāṇti-tirumañcanattār-velam. ${ }^{27}$ Though it may be argued that Pāṇti was a Chola epithet, in the latter title Pāṇti is syntactically separated from the royal name, suggesting that it probably denoted something else. We may instead render the phrase as "the velam known as Rājarāja (comprised) of those from Pāṇṭi (maṇụalam) selected for the ceremonial bath". This reading suggests that at least some velam titles may have indicated the personnel which staffed them, particularly when such naming increased the grandeur of the king as a warrior. We shall see that other evidence supports this as well.

Various scholars have interpreted the velam as a physical space - a "palace", "harem", "prison" or "urban unit". Two elaborate and important inscriptions on the Rājarājeśvara temple at Tanjavur are particularly germane in this regard, as they give more information than usual about the velams they name. ${ }^{28}$ The inscriptions, which record arrangements for temple illumination, mention some seven different velams and at least sixty-four individuals associated with them. They seem to speak of men and women "residing in" various velams (...velattu irukkum). What is more, they also specify the general locations of the velams, with all but one of the seven being "outside" (purampati) and the other (Pānți-velam) "inside" (ullālai), the central urban area. It is unlikely that velam here refers to a palace. Chola royal inscriptions often mention palaces $(k \bar{o} y i l)$ or places within them (cālai, mantapam, mälikai), usually in connection with specifying the king's location when issuing an order. A number of royal orders, for example, were issued while the king was "pleased to be seated in the ceremonial bathing hall (tirumañcanacālai) within the palace". ${ }^{29}$ It is clear that such places, where the king's actual bath must have taken place, must be distinguished from the bathing velams.

This fact has no doubt led scholars to interpret the bathing velams at Tanjavur as "quarters" occupied by those who had to supply water or services for the royal bath, and more generally as semi-urban settlements. ${ }^{30}$ This interpretation would seem to be supported by the locative descriptions of the velams at Tanjavur. Yet we find that one of the most prominent of the Tanjavur bathing velams, the Uyyakoṇtān-terinta-tirumañcanattārvelam, is also encountered in a record dated in the fifth year of Rājendra II's reign (1057), where it is clearly said to be located in Gangaikondacholapuram. ${ }^{31}$ The later appearance of this velam in a

27 SII 2.94 and 95.

28 SII 2.94 and 95.

29 For the palace at Tanjavur, SII 2.1; at Gangaikondacholapuram SII 3.20; at Kanchi, R. Nagaswamy, "Archaeological finds in south India: essalam bronzes and copper plates", Bulletin de l'École Française D'Extrême-Orient 76, 1987, 34; and Muțikoṇuacholapuram EI 22.35.

30 The suggestion of the editors, SII 2.95, introduction. See also Venkataraman, Rajarajesvara, 251

31 ARE 121 of 1914. 
different locale makes it clear that it could not have been an urban settlement or residential quarter. The locative references in velam inscriptions suggest instead that velam personnel were merely quartered in these places. Less than half of the remaining velams cited in Chola inscriptions include any information at all on their locations, and when such information does occur, it remains conspicuously generic (being either in Tanjavur or Gangaikondacholapuram). I would suggest that the term is better conceived, following Subburayalu, as a collection of servants in the first instance and by extension also came to designate the place where these servants would have resided. The quartering of velams both in and outside the central city of Tanjavur was no doubt significant, but we currently possess neither enough information on the urban layout of Chola period Tanjavur - its palaces, residential quarters, fortifications or city limits - nor the total number and location of its other velams to make any solid conclusions on this point.

The Tanjavur inscriptions are anomalous from another point of view, which raises further questions about the nature of velams. The "residents" of the velams in the Tanjavur inscriptions are for the most part said to be shepherds (itaiyan), not palace menials or military personnel, as is typical in all other epigraphic instances so far found. The inscriptions record the deposit of large numbers of livestock to well over a hundred shepherd households for the daily provision of oil necessary to burn temple-lamps at Rājarājeśvara. ${ }^{32}$ The animals were donated by the king, high-ranking courtiers, military groups, and, notable for our purposes, a woman attached to one of the velams in question by the name of Varakunan Eruvattūr. The majority of shepherd families in receipt of these animals lived beyond the inner urban area of Tanjavur, "in" velams and other places noted in the inscriptions, but a significant number lived in various villages at a greater distance from the capital. It is difficult to understand what connection this subset of shepherds, numbering some 63 families, had with the velams they are described as "residing in". It is possible that velams may have had more differentiated functions and diverse personnel within their ranks than other inscriptions have led us to believe. Shepherds may have been "attached" to palace establishments to supply them or the palace with oil. In view of the complex and manifold nature of the royal retinues, this is certainly possible. Yet if this were the case, one might expect such shepherds to be distinguished in title from their counterparts who were not associated with velams - and we find no such titles. Nor do we find any other instances of shepherd/herding castes throughout the Chola period with velam affiliations as identifiers. ${ }^{33}$ For this reason it seems more likely

32 See George Spencer, "Temple money-lending and livestock redistribution in early Tanjore", Indian Economic and Social History Review 5/3, 1968, 277-93, and also Heitzman, Gifts of Power, 121-42.

33 Based on information gathered in N. Karashima, Y. Subbarayalu and T. Matsui, $A$ Concordance to the Names in Cōla Inscriptions (Madurai: Sarvodya Ilakkiya Pannai, 1978), 3 vols. One of the several fragmentary inscriptions found in the courtyara of the Tanjavur temple records a joint gift made by a woman named Maraikkāțtațikal, of the Mañcanattār-velam, and Koḷūran Kañāalan, a shepherd (mañrāạti), see $A R E$ 576 of 1971. 
that the shepherds lived in proximity to the quarters of the velams but had no formal affiliation with them. ${ }^{34}$

To conclude the discussion so far, it would seem that the term velam denoted a collection of servants connected with the royal household and by extension may have loosely referred to the residential quarters where such personnel were domiciled. The evidence suggests that many such establishments co-existed within the rule of a single monarch, often being named after members of the royal family. But despite the titular links to the royal family, velams seem to have had no single principle of nomenclature. Like other institutions associated with the royal court, velams often bore the titles and names of the royal family in a commemorative rather than a functional sense. Moreover, the titles of various velams clearly suggest a hierarchy perhaps based on size and seniority. Finally, a number of velams were clearly named after specific tasks in court ceremonial and possibly after the original provenance of their members.

\section{The personnel of velams}

The categories of people most often associated with velams in inscriptions are pentâtți, and to a lesser extent kaikkōlar. Kaikkōlars, literally "those of strong arms", were a class of apparently hereditary military retainers who often resided in proximity to the palace and who formed an integral part of the Chola armies. Kaikkōlars appear as members of velams in just five instances, one in the tenth century and the other four in the twelfth. ${ }^{35}$ Kaikkōlars, however, sometimes appear connected through kinship to others (mostly women) who are velam-identified, a point of some significance. ${ }^{36}$ While kaikkōlars appear in a small number of velam-related records, their overall presence in Chola inscriptions is far more extensive, as they formed part of the elite military coteries of the Chola kings, being selected for staffing personal entourages (parivārams) and perhaps acting as body guards, but at the very least constituting part of an inner core of permanent troops around the royal household. ${ }^{37}$ Even in early Chola inscriptions, these men possessed a strong corporate identity which, like other military groups, seems to have been transformed into a caste status by the end of the Chola era. ${ }^{38}$

34 It is interesting that the pentâtți Varakunan Eruvattūr who is a donor of sheep to the same velam with which she is associated is not described as "residing" (irukkum) there, but with the standard formula of $x$ velattup pentatt ti $y$. In fact, use of the term "reside" is not found in any other velam-related record, being unique to the shepherds at Tanjavur.

35 For the tenth century see SII 4.536; for the twelfth century, see SII 23.279, SII 23.281, SII 5.697, SII 5.698.

36 See SII 26.669; SII 23.356; SII 5.539; SII 22.27.

37 See the discussion of P. Sundaram, "Chola and other armies - organization", in Prasad (ed.), Historical Perspectives on Warfare in India, 190-1.

38 In post-Chola times the term kaikkōlar denoted a caste of weavers who traced their origin to military groups of the Cholas. When this occupational caste identity developed is less clear, with some scholars (Heitzman, Gifts of Power, 150, and 
Female members of velams are usually described as pentatttis, a difficult word because of a long historical sedimentation and multiple usages. Though used informally in contemporary Tamil to mean "wife", in medieval times the term denoted a woman of generally servile status ${ }^{39}$ and most usually one connected with the royal palace in some capacity - what Leslie Orr has called a "palace woman". ${ }^{40}$ It literally meant a woman "ruled" or a "slave/servile woman", but the generic nature of the vocabulary of servility prevents any conclusions about the status of such women on the basis of terminology alone. ${ }^{41}$ In at least one reference a pentätti $i$ seems also to be identified with a term which less ambiguously denoted a slave (atiyal for atiya $\bar{l}$ ), but for the same reasons this may mean very little. ${ }^{42}$ Not all inscriptional references to pentatttis mention velams - women are sometimes simply identified as pentatttis or as the pentāttitis of the entourage of a particular member of the royal family. ${ }^{43}$ In a few cases women associated with velams and other palace establishments are simply referred to by generic words referring to women (pentulpentir) - terms we also encounter for women attached to the royal kitchens - but it is likely that in the cases of velams the terms pentattiti and pentir were interchangeable. ${ }^{44} \mathrm{It}$ is difficult to gauge the significance of the absence of velam affiliations for pentâtțis and pentātți status for royal servants not apparently attached to velams. ${ }^{45}$ It may be that pentatțti referred to a more generic category of

Subbarayalu, Studies in Chola History, 108) arguing that it was primarily later, and others holding that it was already in place during Chola times (Vijaya Ramaswamy, Textiles and Weavers in South India (Delhi: Oxford University Press, second ed., 2006), 13 ff.).

39 The term for wife which occurs in inscriptions is typically manavättit, see SII 13.196. The term pentattti may in some cases have designated simply an unmarried woman, as in Tiruppāvai 11. I'd like to thank Archana Venkatesan for drawing my attention to this citation.

40 See Orr, Donors, Devotees, and Daughters, 40-1.

41 The word is formed by adding the suffix - $\bar{a}$ ! (a verbal root meaning "to rule, receive, control or maintain", or noun meaning "man, servant, slave, labourer") to the noun pen, meaning "woman". See Orr, Donors, Devotees, and Daughters, 212 n. 5.

42 SII 23.278.

43 See, for example, ARE 88 of 1928; ARE 69 of 1926; and SII 5.700. Orr has identified forty-one instances of pentâtți in Chola inscriptions, with twenty-six (over 60 per cent) mentioning some association with a velam (Orr, Donors, Devotees, and Daughters, 212 n. 5). My own data suggest a somewhat higher numbers of both pentâttti instances and velam associations.

44 For the use of pentulpentir to refer to palace personnel and members of royal entourages, see $A R E 13-14$ of 1936 and $A R E 156$ of 1939. For references to kitchen staff using the terms pentāttti and pentu, see SII 19.98; TAS 1.8.1; SII 7.981; ARE 8 of 1936; SII 6.34; and $A R E 361$ of 1918. I would like to thank Uthaya Velupillai for the last two references. Inscriptions mentioning the royal velams (Perumāl-velam) of the Kongu rulers describe their donors either as perumäl velam pentāttis or as "among the women of the velam" (perumāl velattil pentukalil), see ARE 334 of 1928; ARE 126 of 1915; ARE 809 of 1983; and ARE 825 of 1983.

45 Two adjacent inscriptions at Uțaiyārkuți (South Arcot) commemorating gifts probably made on the same occasion by two women, one identified as "singing" in the Periya-velam at Tanjavur and the other simply as a pentattti, SII 19.10, 12. The apparently accidental omission of the term pentattti in the first inscription may parallel an omission of a velam affiliation in the latter. 
female servant who took on a variety of roles at the Chola court, but the majority of records place them within velams, and I will assume that this was their typical affiliation.

Inscriptions are for the most part silent as to the social origins of pent $\bar{a}-$ $t t i s$, but exceptional evidence comes from the late twelfth century, when an inscriptional eulogy (meykkīrtti) of king Kulōttuñka III (1178-1218) describing his protracted struggles with Vīra Pāndya of Madurai, boasts that having beaten the Panndya king on the battlefield, he "caused the best of his women to enter his velam" ${ }^{46}$ A later version of the same eulogy adds that the Chola king caused Vìra-Pāṇdya's "young queen" to enter his velam (matakkotiyai ve[lam] erri). ${ }^{47}$ The Kalinkattupparani, the famous court poem composed during the reign of Kulōttunka I, which contains the only attested literary use of the term velam, would seem to corroborate the meykkirtti of Kulōttunka III. The first substantive canto of the poem takes the form of an entreaty to the women of the royal city to "open their doors" for the returning Chola army. A string of verses is specifically addressed to women of the velam:

You gentle women of the Pāndya country, the flag of which bears the fish, who have entered the vellam after running through the wilderness in tears, open your doors! Women of Tulunāțu, women of Malaināṭu, give tribute to Kulottunika, from the land of the splashing waters, open the doors to your houses ... You Karṇāta women, approaching uttering a confused mix of beautiful words in Tamil and Vațuku in your gentle speech, open your doors! $4^{48}$

The Kalinkattupparani and Kulōttunka III's meykkirtti make clear that at least some of the women of the velam were war-captives. ${ }^{49}$ The practice of capturing or forcibly abducting women as part of annual military campaigns in rival kingdoms is well-attested in south India, as "seizing women" was a regular boast in the royal eulogies which cover the walls of scores of Chola period temples. Medieval south Indian armies travelled with large trains of supporting personnel - including members of the royal family and various ranks of male and female servants. In the case of defeat, these retinues often fell into the hands of the enemy. In their meykkirttis, the Cholas are often quite particular about the fate of women captured from their rivals. ${ }^{50}$ The forcible abduction of women of lesser rank from the

46 SII 22.42; also ARE 254 of 1925.

47 SII 3.88.

48 Kalinkattupparani, ed. Pe. Palanivēla Pillai (Chennai: South India Saiva Siddhanta Publishing Works, 1961), vv. ${ }^{-4} \overline{0}-3$.

49 See the discussion of C. Ilavaracu in his Parani Ilakkiyankal (Chidambaram: Mānivācakar Nūlakam, 1978), 53-4, where he contends that among the women of the royal capital depicted in the second canto were contingents of women received as tribute from subordinate rulers or captured during wars.

50 See especially the meykkîrttis of Rājendra I's successors, particularly Rājendra II (1052-64), SII 22.80 and Vīrarājendra (1063-70), EI 21.38. In some instances they were "defaced" - their noses shorn off - as when Vīrarājendra boasts of severing the 
cities and countryside is also known. A famous Chalukya inscription dated in 1007, at the village of Hottur in contemporary Dharwar district, describes the campaign of a large Chola army from the other side, as it "ravaged the whole country, murdering women, children and brahmins, seizing women (pendiram pididu) and overthrowing the order of castes ..." .51 Though some of these claims are surely rhetorical, the repeated and often very specific emphasis on tribute and capture cannot be ignored. Such references, both literary and epigraphical, strengthen the contention that at least some velams (i.e. Pānti-velam) may have been named after the regional origins of their inhabitants.

One of the medieval ula poems composed at the Chola court describes the crowds of women who lined the streets during royal processions as being descendants of women brought to the Chola capital from victorious campaigns and settled by the king in areas assigned to them. ${ }^{52}$ Though the word velam is not mentioned in the poem, the passage clearly invokes these establishments and is broadly corroborated by a contemporary Sanskrit text on architecture, Mayamata, which recommends that the royal street (räjavithi) be lined with mansions ( $m \bar{a} l i k \bar{a})$, where the king's retinue was to reside. ${ }^{53}$ Such a set-up calls to mind the dispersal of velams across the urban landscape mentioned in the Tanjavur inscriptions, though without any reliable urban geography of the medieval city, this cannot be confirmed.

Closely related to capture through war was the receipt of women as tribute from subordinate kings, a practice which was not unknown elsewhere in early medieval India. The Kalinkattupparani, which portrays the splendour of the assembled Chola court, lists among the annual tributegifts required of subordinate kings, "the forehead bands (pattam) of women who are rightfully yours". ${ }^{54}$ At least one pentâtt $i$ known from inscriptions, a woman who served Rājarāja's queen Pañcavanmāteviyār in the Kotaṇtarāmaveḷam at Tanjavur, has a name, Vānakovaraiyan Porkāli, which identifies

nose of the Chalukya mahādandanāyaka Cāmuṇarāāja's only daughter, the beautiful Nagalai, EI 21.38, SII 3.20. In other cases these women were simply added to the king's retinue, as in Virrarājendra's claim to have taken large numbers of elephants, camels, horses, banners, queens, and women of lesser rank left on the battlefield by the retreating Chalukya monarch, SII 3.29.

51 EI 16.11a.

52 In describing the crowds (kuläikal) of women who appear on the street awaiting the king, Otțakkūttar lists the women (matantaiyarum, mañkaiyarum, mātarum, etc.) captured (kaik kontu, etc.) by the Chola king or acquired as servants of women given (in marriage) to him - all by way of explaining that "the tender girls descended from the women of these various respected lineages, who have a right to the palace crowd together (mutalāya cāyal aramakalir tattan tirumarapil kōyilurimaik kulānerunki) in the gateways, residences and mansions ready to see the king. "Irācārācacōlanulā", in Mūvarulā, ed. U. V. Cāminātaiyar (Chennai: U. V. Cāmināthaiyar Nūl Nilaiyam, 1992), vv. 70-82, esp. 79. See also the remarks of G. Thirumavalavan, Political, Social and Cultural History of the Cholas as Gleaned from the Ulā Literature (Thiruvathipuram: Ezhilagam Publishers, 1991), 134-5.

53 Mayamata: Traité Sanskrit d'Architecture, ed. and trans. Bruno Dagens (Pondicherry: Institut Français d'Indologie, 1970), 10.74-5.

54 Kalinkattupparani, v. 336. 
her with a lineage known to be subordinates of the Cholas. It is possible that this woman, who was clearly not a wife but a servant, was presented as a gift to the Chola family as a token of friendship and submission.

It is likely, then, that many women entered velams through military conquests and as political tribute. Indeed, the period of the greatest number of velams mentioned in inscriptions coincides neatly with the military successes of the Chola armies in the eleventh century under Rājarāja I and his son Rājendra I. It remains an open question, however, to what extent velams were filled exclusively with such women and whether there were other methods of recruitment into velams. Though pentạttis shared a number of characteristics with temple women, there is no existing epigraphic evidence of the presentation, sale or purchase of a pentātti to or by the royal court as we sometimes possess in the case of temple women. Assuming that at least some pentâtttis entered palace service as war booty, this may have obviated the need to acquire them through purchase. It is also true that such transactions would not have appeared in the inscriptional record, as they had little relevance for temple affairs. Important in this regard is an inscription dated to the reign of Kulottunka I, which records the transfer of a temple slave found in the king's retinue back to the temple authorities, which involved removing the king's mark (nam ilaccanai alittu) from the woman's body and branding her with the god's stamp as a sign of her proper ownership. ${ }^{55}$ This inscription suggests that the lower ranking women among palace servants may have overlapped with their temple counterparts.

The inscriptions, however, present another sort of evidence which bears on the identities of pentāttis - their personal names and kin-affiliations. In all cases the inscriptions record the names of pentatt $t$ s, but these are often difficult to interpret. Some pentatttis, for example, appear to have had male names ${ }^{56}$ - a fact which may indicate either that "male" names could be taken by women or that pentätti indicated a gender role rather than a biological identity. ${ }^{57}$ Pentạtțis often had compound names, like Kātan Āccatevi, Kallici Uttamata, or Kāri Cātti, which raises the question of the significance of each name segment. It is possible that in some cases,

55 ARE 141 of 1922, discussed in Nilakanta Sastri, Colas, 356. The term used in the inscription for this woman, not surprisingly given her discovered identity, is tevaratiyār rather than pențāttit.

56 As in the case of a pentattti of the Melai-velam with the single name Rāman, ARE 340 of 1927.

57 For the latter interpretation, see Kōvintarācan, Kalvețtuk Kalaiccol Akaramutali, "vēlattup pentātttil" and "pențătti". Kōvintarācan's conclusions seem to be based on the weakly substantiated assertion that pentatttis were cooks at army encampments. The evidence he cites is both meagre and inconclusive, and demonstrates neither the claim that the primary activity of pentāttis was cooking (he ignores the other dimensions of velams discussed above), nor that pentatțtis were actually men. While it is possible that terms like pentattti may not have conformed to the gender identities of their bearers, it is more likely that proper names did not. The large body of evidence analysed by Leslie Orr suggests that the use of "male names as given names for women" was widespread in Chola times. See Orr, Donors, Devotees, and Daughters, 147. 
paternal names were prefixed to proper names, as has been common practice in south India, though the evidence is not conclusive. ${ }^{58}$ In some compound names the first element is clearly feminine, and others would seem to incorporate the name of a deity or place as the first element of a compound name. There is, therefore, no consistent naming pattern among pentâttis. What is at stake in understanding the significance of pentātti name segments is their possible identification of natal or conjugal kin. Leslie Orr has suggested that the names of many tevaratiyār in the inscriptions may not indicate kinship links of any sort. ${ }^{59}$ Name segments aside, in no instances are pentattis explicitly identified as either the daughters or wives of men, even when their own children are mentioned. This apparent absence of male kin remains in stark contrast to the identification of women from the higher castes. ${ }^{60}$ On the other hand, many temple slaves were designated as "daughters of god" and male palace servants as "work sons" (pani makan). Whatever the connotations of this quasi-kin terminology, the men and women of the velam did not define themselves through normative natal and conjugal kin affiliations.

The only kin definitively mentioned in connection with pentatttis were mothers, children and siblings. In a number of records donors identify themselves as the mothers, sons, daughters, brothers or sisters of pentātt tis, in some cases making gifts on behalf of, or with, their kin. ${ }^{61}$ Fathers and husbands of these women are conspicuously absent in the inscriptions. The fate of pentâtți children in relation to the complex institutions surrounding the court is uncertain. Young males may have entered the ranks of kaikkilars, as we have two instances of kaikkōlars either making grants on behalf of velam women or identifying themselves as children of a velam linked pentattti. ${ }^{62}$ This might fit well with the evidence we have from separate records, mentioned above, which identify kaikkōlars themselves as members of velams. ${ }^{63}$ But most kaikkōlars seem not to have been directly linked with velams, instead constituting separate units within the Chola army - which does not of course preclude their origin from pentâttis. But kaikkōlars could rise to higher ranks within the court hierarchy, and we have records suggesting they were sometimes attached to the personal

58 On the practices of naming in medieval south India, see Subbarayalu, Matsui, and Karashima's introduction to A Concordance to the Names, vol. 1 .

59 Orr's findings suggest that most women did not incorporate the names of their fathers into their own, see Donors, Devotees, and Daughters, 147, 248 n. 16.

60 See the discussion in Orr, Donors, Devotees, and Daughters, 154-5.

61 See SII 17.530 for the gift of the children (makkal) of a pentatttti of the Kilānatikalvelam; SII 17.480 for the gift of a man for his elder sister who is identifie $\bar{d}$ as the daughter of a pentattti of the Periya-velam; and ARE 63 and 64 of 1928 for the joint gift of a pentātti $i$ and her daughter, both residents of the Śivapādaśekhara-terintatirumañjanattār-velam.

62 See SII 26.669 for a kaikkōlar whose mother was a pentätți in the Irācakesari-velam; and SII 23.356 for a kaikkōlar making gifts for various women in the Kotantavelam. The editors have assumed in the latter case that the women were relatives of the donor, though the inscription does not specify this.

63 We have one tenth-century record of a kaikkōlar attached to a velam, SII 4.536; and four twelfth-century records, SII 5.697; SII 5.698; SII 23.279; SII 23.281. 
retinues of various members of the royal household and in some cases enjoyed land tenures known as virabhoga by order of the king. ${ }^{64}$ Whatever the case, there seems to be some special relationship between kaikkōlars and velam women. They often appear together as donors in clusters of inscriptions at key temples. This seemingly special connection between velam pentâttis and kaikkōlar units also seems to fit with the Kalinkattupparani's request to the women of the velam that they "open the doors" to the returning soldiery of the Chola army. It may thus be that one important function of the velam, as Nilakanta Sastri suggested long ago, was to supply the court with a regular source of loyal military retainers whose loyalties were confined entirely to the extended household and its master. ${ }^{65}$

The few records which mention mothers and daughters are difficult to interpret. ${ }^{66}$ Only rarely are both women identified as belonging to the same velam; more typically the evidence is ambiguous, giving no clear indication of velam affiliation or pentattti designation. ${ }^{67}$ It is difficult to know how much weight to give such omissions. While any firm conclusion would be hasty, the evidence hardly rules out the possibility that the daughters of pentättis may have been born into the same condition as their mothers. ${ }^{68}$ The comparative frequency of pentâtțis in the inscriptions across many generations may itself account for the absence of explicitly identified daughters. If pentätti mothers did not identify themselves with their natal or conjugal kin, being instead identified entirely with the extended household of the royal family (except in rare circumstances when they made gifts with or for the merit of their children) then their daughters would have presumably done the same. While male children may have had the opportunity to pursue military careers and potentially head their own households, daughters may have been simply absorbed "silently" into palace establishments without the benefit of any lineal identification. Pentâtți siblings may not have always shared the same fate. A tenth-century record from Tirupundurutti mentions a pentatt ti by the name of Perranakai of the Periya-velam, who is identified as the younger sister (taikayār) of a woman called Vikramābharani[yār], apparently not attached to this velam. Vikramābharani, however, appears in two later inscriptions, one from

64 See $A R E 69$ and 72 of 1926, where the village of Kulōttunkacōlanallūr is designated as vīrabhoga for kaikkōlars from Merkā-nāțu who were of lesser (śirudanam) rank and served in the palace at Gangaikondacholapuram.

$65 \mathrm{P}$. Sundaram has also suggested that velams were training establishments for Chola military personnel, see Sundaram, "Chola and other armies", 191.

66 Beyond the references cited in note 61, see ARE 212 of 1911 for a pentattti of the Abhimānabhūṣaña terinta tiruvanțikāppu-velam, who devotes the merit of a gift to her daughter, and ARE 149 of 1932 for joint gift by a pentâttti of the Mañcanattārvelam with her mother and sister.

67 See ARE 63 and 64 of 1928 for a mother and daughter identified as pentatttis belonging to a velam, SII 17.480 for a mother identified as the pentạtti of a velam but not her daughter; and SII 23.45 for a daughter identified as the pențatți of a velam but not her mother.

68 This is the implication of the Irācarācacōlanulā, which speaks of generations of women from different lands living by the order of the king. 
Tirukkalavur and the other in a fragment fround at Tanjavur, where she is referred to as a pentattti, in one case as the personal servant of the Chola queen Villavan Mahādeviyār and in the other as a resident of the market in Tanjavur known as Ponnamaraiyanañkāti. ${ }^{69}$ If these identifications are correct, it would suggest that these sisters, Perranakai and Vikramābharaṇi, though both of pentâttti status, had different careers, resided in different places and had different institutional affiliations.

Some pentâtti names reveal clear evidence of stratification and the receipt of various forms of favour among the women of the velam. Some women seem to have entered the royal household with elevated rank women of high standing given as tribute or captured from the chiefly and royal families of subordinate lineages - like Vānakovaraiyan Porkālì, a servant of the Chola queen Pañcavanmādeviyār in the Kotaṇtarāma velam, who seems to have retained the title of an earlier affiliation with a feudatory family. ${ }^{70}$ Others seem to have acquired titles of distinction once within the velam, like the pentātți Tevayan Pulalakkan of the Kilai (Kilānatikaḷ?) velam, who was also known as "Crest-Jewel of the Earth" (Avaniśsikhāmaṇi), or Cāttan Rāmadevi of Rājendracola-periya-velam, known from two inscriptions, who took the title "Ruby of the Sacred Jambu Fruit" (Tiruṇnāvalmāṇikkam). ${ }^{71}$ The term mānikkam, or "ruby", seems to have been a title incorporated into the personal names of a number of pentatttis in the eleventh century, and was even more widespread among temple women. ${ }^{72}$ Though its particular significance is uncertain, mānikkam clearly had a generally honorific connotation, as is confirmed by two eleventhcentury inscriptions which mention a woman with the title Sembikulamāṇikkiyār "Ruby of the Chola family", who is also termed an anukki, or "intimate". ${ }^{73}$ The term anukki, (masculine, anukkan) was clearly a title of favour bestowed on those close to a member of the royal family. In the case of women, this intimacy may or may not have involved sexual relations, but appears to have indicated a status distinct from the category of pokiyār, or "concubine". It is also unclear to what extent - if any - the term pentâtți itself implied sexual relations during Chola times. Women with the titles of

69 See $A R E 99$ of 1931 for the Tirupundurutti record, dated in the thirty-fourth year of Parāntaka (941 CE), mentioning Perranakkai and Mutta Vikramābharaṇiyār; SII 3.110 for the Tirukkalavur record, dated to the thirty-ninth year of Parāntaka's reign (946 CE), mentioning Nakkan Vikramābharaṇi as a pențătṭi of Villavan Mahādeviyār; and ARE 574 of 1971 for the Tanjavur fragment, dated in the eleventh year of Âditya II's reign (967 CE), recording the donation of Piccan Vikramābharani, resident of Ponnamaraiyanañkāți. Though the prefixed names of Vikramābharani differ, I assume that they nevertheless refer to the same person, as each is a common term for Śiva, suggesting they were loose titles indicating devotion. The term mutta, however, could be an epigraphic variant of mütta, "elder", which would be a loose descriptor in keeping with the purport of the first inscription.

70 SII 23.278.

71 SII 3.201, ARE 424 of 1962.

72 In addition to Cāttan Rāmadevi, see SII 22.291, ARE 323 of 1927. On the occurrence of the title ämong tevaratiyār, see Orr, Donors, Devotees, and Daughters, 148.

73 ARE 328 of 1965 and ARE 553 of 1994. 
pokiyār or anukki often appear as donors in inscriptions with no velam associations. Two early Chola inscriptions at different temples record the gift of lamps by one Nañkai Cāttaperumānāār, a "concubine" (pokiyār) of the king Âditya I (871-901), and very extensive gifts made by one Nakkan Paravai, identified as an "intimate" (anukki) of Rājendra I - neither of which mention pentattti status or affiliation with a velam. ${ }^{74}$ On the other hand, Căttan Rāmadevi, the pentạtți mentioned above, takes the title of "intimate" (anukki), suggesting that women of the velam were eligible for this distinction. ${ }^{75}$ Indeed, a fragmentary inscription from Gangaikondacholapuram registers the gifts of a number of anukkiyār and pentatttis, both of whom seem to have belonged to the Tirumañcanattārvelam. ${ }^{76}$ There also seem to be records of children whose mothers were favourites within a velam. ${ }^{77}$

Judging from this terminology of hierarchy and the endless sexualization of palace women in court literature, the possibility remains that the dynamics of favour for women of the velam may have been closely tied to sexual relationships with members of the royal household. Having said this, the reality of such relationships, beyond literary representations, remains unknown. None of the children of pentatttis we find in inscriptions mention their paternity, and we thus have no way of understanding who their fathers were. This, however, may be significant in itself, for these women seemed never to have had the benefit of legalized marriage, so their relationships remained necessarily ambiguous and invisible. The degree to which favour itself was imagined through the language of intimacy is very much reflected in the ula literature, with its treatment of the various generations of desiring women in the king's retinue from childhood to sexual maturity. Though there is surely a formulaic element to the genre, it nevertheless envisions the palace woman's transition to maturity as at once a romantic fantasy and a quest for intimacy and favour. This quest was no doubt significant in shaping the horizons of well-being in the life of a pentātți.

Like their temple counterparts, velam pentāttis received maintenance and seem to have been able to accumulate modest amounts of wealth. That slaves and others of servile status attached to powerful households were able to enjoy certain circumscribed privileges and material support was not at all unusual in medieval India, nor in Chola times. In one record, for example, we have a slave (atiya $\bar{l}$ ) donated to a temple with a maintenance

74 SII 13.219; SII 13.247; SII 4.223.

75 ARE 401 of 1921. See also 104 of 1925, which mentions Araiyan Anukki of the Periya-velam.

76 ARE 325 of 1965.

77 See SII 17.480 for a record where a man with the unusually long (and ambiguous) name, Irumuțicōla Aṇnuki (li) Cāman-Accan I. Kanāccan identifies himself as the son of a pentätți named Ilattanankai of the Periya-velam, whose status of "anukki" may have been encoded in her son's name. There is also the case of Aț[n]ukkan Mahamalli of the Uțaiyār-Irācakesari-velam, who appears as the mother of a kaikkōlar donor, SII 26.669. As anukkan is the masculine form, it remains unclear whether she, or perhaps a male relative, held this title. 
grant (jīvanam) for picking flowers in the temple-garden. ${ }^{78}$ Unfortunately, inscriptions have very little to say about maintenance arrangements for palace women, a situation which contrasts markedly with that of temple women. Inscriptions relating to penta țt tis generally indicate only that they were able to make modest gifts to temples. As with temple women, most inscriptions record gifts of money for the establishment of perpetual lamps in temples. How pentattttis acquired this wealth is unclear - they may have received it as maintenance (clothes, jewellery, daily or yearly allowances for food or land) from the royal household, as support from children or others, or it may have accompanied them into servitude.

Several features of the epigraphic evidence also suggest that the capacity to dispose of wealth among palace women may have been more circumscribed than has been previously assumed. First, unlike the donations of temple women, the geographical distribution of the inscriptions of palace women and pentatttis is considerably more restricted. Barring some notable exceptions which I shall treat below, the overwhelming majority of their activities are confined to the temples in the central region of the Chola empire (see figure 1), or Cholamandalam. Their activities, in other words, followed the practices of patronage followed by the royal household itself; they tended to make gifts at those temples heavily supported by the Chola court. When pentātt ti inscriptions appear outside of the immediate Chola heartland, they often appear in conjunction with the specific tours of royal retinues. One of the most distant penta $\operatorname{t} t+i$ inscriptions, for example, occurs at the Guhanāthasvāmin temple at Kanyakumari, in the twenty-fourth year of Rajendra I's reign (c. 1036) by one Colakulavalli (lit. "Creeper of the Chola family"), a pentattti who cooked for the king. While in isolation the inscription may appear enigmatic, when read with surrounding epigraphs (some six other inscriptions by various members of the Chola family, including three Chola kings, and courtiers, some of whom hailed from the same locale as Colakulavalli) over a span of several decades, it becomes clear that the pențātt ti's gift was not an isolated incident. ${ }^{79}$ Indeed, while a more detailed study of pentātți inscriptions in relation to their epigraphic contexts still needs to be conducted, my preliminary analysis suggests that this state of affairs obtained within the Chola heartland as well. Gifts of palace women typically followed the patterns of, or were made in conjunction with, members of the royal household. So during the reign of Āditya II we find separate records of some ten donations by various members of the royal household, including the queen Sembiyan-Māteviyār, two pențățtis, and members of five different kaikkōlar units, apparently donated on the same occasion, to the Ananteśvarasvāmin temple in Uțaiyarkuți, South Arcot. ${ }^{80}$ Among the fragmentary inscriptions at Gangaikondacholapuram, we find gifts made by pentātțis and anukkiyār together. ${ }^{81}$ At the Gomuktīśvara

78 SII 22.141, discussed along with other cases by Orr, Donors, Devotees, and Daughters, 127.

79 TAS $1.8 .1 \mathrm{ff}$.

80 SII $19.10 \mathrm{ff}$.

81 ARE 325 of 1965. 
temple in Tiruvāduturai, an inscription, dated again to the reign of Rājendra I, lists various gifts and images presented to the deity by several persons including Irāman Abhimānatonngaiyār, mother of TrailokyaMāteviyār (mother of Rājendra), the preceptor of Rājādhirāja (Rājendra's son), and of various servants of the Periya-velam. ${ }^{82}$ Palace women thus rarely acted in isolation, and it is perhaps not implausible to suggest that their individual ability to dispose of wealth as individuals was circumscribed by the hierarchy of life at court. The real ownership of resources behind conventionalized gift-giving, therefore, cannot be assumed at face value. An unusual record dating from the time of Rājarāja I seems to record the intervention of the palace kaikkolars on behalf of the royal household to collect payment on a loan taken by a powerful brahmin member of the sabhā from a pentạtți who belonged to the Mañcanattārvelam. ${ }^{83}$ As he had in the interim died and no relatives were willing to settle the debt, the palace took over the debtor's property, which had passed on to his son, and sold the land to the temple. In this instance it would seem that the palace acted on behalf of the pentattti and had some claim over wealth which she appears to have freely lent as an individual. Much work still needs to be done on the power dynamics of collective possession and giving in South Asian religious contexts.

\section{Observations and conclusions}

Inscriptions suggest that the velam as an institution underwent significant change as the Chola empire evolved. During the "early" Chola period (c. 925-985) in the tenth century, nine different velams are mentioned in approximately fifteen inscriptions, while during the "middle" period (9851070 ) in the eleventh century, twenty-one different velams are mentioned in roughly thirty-five records. Putting aside a cluster of records from the kongu, the later period of Chola rule (1070-1250) saw a marked decline both in the variety and overall incidence of velams in the epigraphic record, with just three different velams mentioned in four inscriptions. The number of velams attached to the royal household, as well as the frequency that their members appear in the epigraphic record, seems to have roughly doubled during the reigns of Rājarāja, and Rājendra and his sons (c. 9851070), when the empire rose to its greatest territorial extent and political power. The military successes of the Chola armies during this period would have flooded the imperial household with the spoils of war, both material and human. Velams must have grown in size and proliferated in number to accommodate the influx of men and women.

The titles of velams show some significant variation between the early and middle periods of Chola rule. Some velams remained important through both periods, suggesting that these were integral and perhaps large and low ranking palace establishments, namely the Periya-velam and Mañcanattār-velam. The early Chola court, however, seemed to 
commemorate a wider number of members of the royal family, including many queens. Nearly half of all titled velams took the name of a queen while just one velam was named after a Chola monarch. This is in marked contrast to the reigns of Rājarāja I and his successors, when only two known velams commemorated queens. During this period, the vast majority of velams were named after the ever increasing titles of the Chola monarch himself (or his predecessors), commemorating victories over rival kings (and perhaps containing the spoils of specific campaigns). Even bathing velams appear with royal titles like Sivapādaśekhara, Uyyakoṇțān, Ilan̉keśvarakulakāla and Telingakulakāla.

Because the titles of velams did not necessarily denote service arrangements, it is difficult to draw firm conclusions from this change. It cannot be argued, for example, that the proliferation of velams with royal titles reflected a concentration of palace servants around the person of the king. A more plausible suggestion would be that these naming practices were an attempt to centralize authority within the extended kin-structure of the Chola court. As the military successes of the ambitious eleventh-century monarchs mounted, new wives and palace personnel, particularly women, were acquired and the Chola household retinues no doubt expanded considerably. This human "inflow" had to be accommodated, a fact reflected in the appearance of new royal residences through the course of the century. With these enlarged retinues now spatially dispersed, there may have been a real need for cohesiveness and loyalty among kin-networks and the large body of servants attached to them. One may speculate that the king-centred nomenclature of palace establishments may have been intended to assert central authority over a dispersed and multi-local family establishment.

It is during this period that velams appear in the provincial courts of the empire, most notably those of the famous Chola-Pandya "viceroys" members of the Chola royal family appointed to rule over the conquered Pandya kingdom during the eleventh century. Two inscriptions from Ambasamudram taluk, Tirunelveli district, in Pạṇtimaṇtalam, dated to the reigns of Jātavarman Sundara Chola-Pandya and Māravarman Vikrama Chola-Pandya in the mid-eleventh century, mention the velams of a Chola queen and one Ceramānār. ${ }^{84}$

More interestingly, a cluster of mostly thirteenth-century inscriptions from sites west of the Chola heartland - at Nerur, Tirumuruganpundi and particularly Kadattur (see figure 1) - dated in the reigns of local kings based in Kongu, mention royal velams (Perumāl-velam). ${ }^{85}$ Sometimes

84 SII 14.170 and SII 14.185. The latter inscription uses the phrase ceramānār velattāl, apparently referring to "a woman in the velam of the Chera king"'. The term velattāl (literally "woman of the velam") is not encountered elsewhere, though the term vellattti (uncertain meaning, perhaps designating either a velam servant as in $A R E 815$ of 1983 or perhaps a female vella älar[?], as in SII 17.518, 528) appears in a number of Chola period inscriptions. The phrase ceramānār probably does not refer to a Chera king as such but to a title of a viceroy or subordinate at court.

85 Tirumuruganpundi, ARE 126 of 1915; Nerur, ARE 334 of 1928; and Kadattur, $A R E$ 809, 815, and 825 of 1983. The Tamilnadu State Department of Archaeology has published a number of inscriptions at Kadattur in T. S. Sridhar (ed.), 
known as the "Kongu Cholas" in the Annual Reports because of their adoption of Chola regnal titles, the history of this dynasty is uncertain. Arokiaswami argued that these kings were "viceroys" who arose after Chola conquests in Kongu during the late tenth and eleventh centuries, but soon became independent. ${ }^{86}$ There is little evidence, however, for a Chola "viceroyalty" in Kongu as seems to have existed in Pantimantalam; the Kongu kings were a lineage entirely local in origin. ${ }^{87}$ The adoption of Chola titles, the occasional expression of tributary status, and possible marital alliances, all suggest, however, a strong link in courtly practice. Burton Stein argued that these "chieftains", situated at the periphery of the powerful Chola empire, adopted its imperial style to gain local legitimacy. ${ }^{88}$ As in Chola lands, velam inscriptions in Kongu often record women making gifts in conjunction with military retinues and their servants. Notably, however, the velams mentioned in Kongu inscriptions, though spanning the reigns of several kings, are not differentiated across generations by any change in name or title.

In the Chola heartland, the epigraphic record shows a dramatic decline in the number of velams after 1070. All of the extant inscriptions from the later Chola period date to the reign of Kulottunika I (1070-1120) and two records refer to a velam apparently named after his son Vikrama. ${ }^{89}$ The donors in these inscriptions, interestingly, are not pențätțis but kaikkōlars, a fact which may reveal a shift in the composition of velams. On the other hand, it is during this period that we have our only definitive references to velams as the repositories of women captured in war - in the reign of Kulōttunka I the court poem Kalinkattupparani uses the term vẹlam to denote a place where captive women were confined, and during the reign of Kulōttunka III an official meykkirtti boasts of the Chola king causing the Pandya princess to "enter his velam". The overall decline of velams in the inscriptional record is perplexing. As is well known, Kulottunka I came to the Chola court from the kingdom of Vengi under fraught circumstances, and it might well have suited him significantly to alter or at least re-orient the existing service arrangements within the imperial establishment. There is evidence that, after assuming the throne, Kulōttunka I developed new patron-client relations and instituted new fiscal policies, with the end, no doubt, of re-aligning the complex network of affiliations that might have potentially challenged his authority. The fate of palace institutions like velams was no doubt caught up in this political history, as they may have

Kōyamputtūr Māvattak Kalvettukal (Chennai: Tamilnadu Department of Archaeology, 2006). See nos. 26, 13, and 55 of 2004, for those cited above and nos. 45 and 48 of 2004, for velam inscriptions not recorded by the ASI.

86 M. Arokiaswami, The Kongu Country (Madras: University of Madras, 1956), 206.

87 V. Ramamurthy has suggested that these kings were a collateral branch of the Cheras, see Ramamurthy, History of Kongu (Part 1) (Madras: International Society for the Investigation of Ancient Civlization, 1986), 248-68.

88 Burton Stein, Peasant State and Society in Medieval South India (Delhi: Oxford University Press, 1980), 312.

89 SII 23.279 and SII 5.698. The remaining references are SII 5.697 and SII 23.281. 
been during earlier crises in the empire, but presently our knowledge of such changes remains too uncertain to say more.

When the Chola empire collapsed in the early thirteenth century, the large palace retinues which served the royal family seem to have also disintegrated. Their members may have been absorbed into the households of the various kings (Pandya, Hoysala and Kādavaraiya) who operated in the Chola heartland from the beginning of the thirteenth century as Pandya armies overran the Tamil lands. These courts, however, do not seem to have continued the institutions from which these women came. Pandya inscriptions, for example, speak repeatedly of capturing queens and highborn women of the Chola court, but do not mention the velam as an institution..$^{90}$ It is also possible that the political instability in the late twelfth and thirteenth centuries may have propelled female (and male) servants of the wider royal household - either voluntarily or through commission into temple service. Although there is no direct evidence of such migration, we do know that there was a certain parity of status between temple and palace women, ${ }^{91}$ and that at least from Rājendra's time women may have circulated (even if by error) between the two spheres. As the temple became an increasingly autonomous and powerful institution in later, and particularly post-Chola times, it may have absorbed kinless women from failing imperial institutions. Once again, the problem is that palace women, to an even greater degree than their temple counterparts, are nearly impossible to "track" in the historical record because of their kinlessness. The kaikkōlars, however, present a different picture. It is clear that by the later Chola period kaikkōlar groups were in the employment of large and powerful temples - which may be significant for pentāttis, as they were sometimes related to them. In post-Chola times, the kaikkōlars gradually shed their association with military retinues of the Cholas and emerged as an occupational status group. The role of kaikkolar-related pentạttis in this longue durée historical process is uncertain, but for the reasons stated above, certainly invisible. With the gradual collapse of the Chola empire, then, these women and their descendants seem to have silently disappeared - either into the courts of other princes, increasingly powerful temple institutions, or the kin structures of nascently forming caste groups. Whatever the case, the institution of the velam, as important as it once had been for the Chola court in the eleventh century, seems to have passed from both practice and memory.

90 See the meykkīrtti of Māravarman Sundara Pandya I from his twentieth year (c. 1236), SII 5.431.

91 For a comparison of temple and palace women, see Orr, Donors, Devotees, and Daughters, 228 n. 22. 